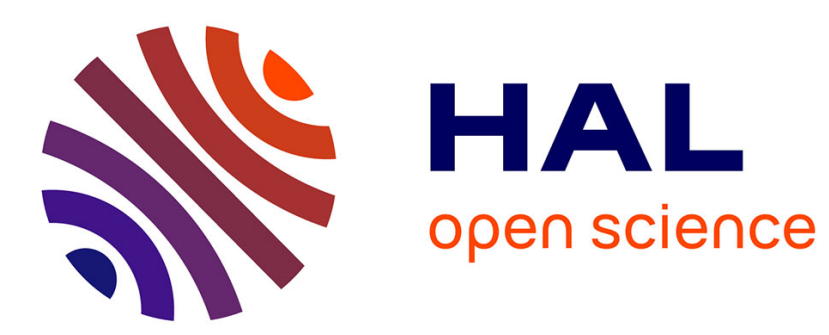

\title{
AFRICAN YOUTH: Stimulus and brake to the effective implementation of the African Continental Free Trade Area
}

\author{
Joseph Mimbale, Jean-Marie Mbutamuntu
}

\section{- To cite this version:}

Joseph Mimbale, Jean-Marie Mbutamuntu. AFRICAN YOUTH: Stimulus and brake to the effective implementation of the African Continental Free Trade Area. Academia Letters, 2021, 10.20935/AL3802 . halshs-03453463

\section{HAL Id: halshs-03453463 \\ https://shs.hal.science/halshs-03453463}

Submitted on 28 Nov 2021

HAL is a multi-disciplinary open access archive for the deposit and dissemination of scientific research documents, whether they are published or not. The documents may come from teaching and research institutions in France or abroad, or from public or private research centers.
L'archive ouverte pluridisciplinaire HAL, est destinée au dépôt et à la diffusion de documents scientifiques de niveau recherche, publiés ou non, émanant des établissements d'enseignement et de recherche français ou étrangers, des laboratoires publics ou privés. 


\title{
ACADEMIA $\mid$ Letters
}

\section{AFRICAN YOUTH: Stimulus and brake to the effective implementation of the African Continental Free Trade Area}

\author{
Joseph Mimbale, University of Kinshasa \\ Jean-Marie Mbutamuntu, University of Kinshasa
}

\begin{abstract}
This paper proposes to explain why African youth can be both an "opportunity" (asset) and a "risk" (problem) in the implementation of the African Continental Free Trade Area (AfCFTA). The paper begins by defining the theoretical framework of the analysis. It then presents the demographic trends in Africa to illustrate the place of African youth in the paradigmatic renewal of the continent. From these trends, it makes two fundamental arguments justifying the interest of relying on African youth in order to capitalize on the gains of the AfCFTA. Finally, this paper considers that relying on youth for effective implementation of the AfCFTA is of undeniable importance for two reasons: (1) Because youth are a catalyst for the future progress of the continent. (2) Because youth can be a liability if nothing is done to address unemployment; boost quality job creation; change the youth training paradigm; and promote STEM (Science, Technology, Engineering and Math).
\end{abstract}

Keywords: African Youth, African Continental Free Trade Area, regional economic integration, Intra-trade 


\section{Introduction}

The AfCFTA will enter into force on May 30, 2019, making it the world's largest tariff zone in terms of the number of participating countries. At this stage, all African countries except Eritrea have signed the accession agreement and 36 countries (including 19 African least developed countries, or LDCs) have ratified it (Luke et al., 2021). This is a dream for many, but it is still far from being realized, given the long road ahead in negotiating all the modalities for implementing the agreement, as well as the gap that exists between regional initiatives and the everyday lives of African people. The AfCFTA reminds us without a doubt of the signing of the Treaty of Rome in 1957, at the origins of what would become the European Union (Bitsch, 2008). Yet, from an economic point of view, Africa would have everything to gain from a common market of 1.2 billion people.

Today, trade between Africa and other continents represents only 3\% of world trade and only $16 \%$ of the trade of African countries is with other countries on the continent. In Europe it is nearly 68\% (CNUCED, 2019). According to the United Nations Economic Commission for Africa, the AfCFTA has the potential to boost intra-African trade by 52.3 per cent by eliminating import duties, and that trade could double if non-tariff barriers were lowered (CNUCED, 2019).

But here we are talking only from a synoptic point of view, that of the states. The objective of this research is to show why youth mobilization and organization is important for effective implementation of the AfCFTA. It begins by setting out the theoretical framework for the research. It then presents demographic trends in Africa to illustrate the place of African youth in the renewal of the continent's development paradigms. From these trends, it makes two fundamental arguments to justify relying on African youth to capitalize on the gains of the AfCFTA.

\section{Theoretical framework}

Two major debates remarkably illustrate the situation of African youth. The first calls for an unparalleled Afro-pessimism for Africa's change. The second, shows an Afro-optimism for the change of the continent. To support this argument, this research considers two dates (2000 and 2011) and two titles ("Hopeless Africa" and "The hopeful continent: Africa rising") from the same newspaper, The Economist. 


\section{A - The Hopeless continent}

At the dawn of the third millennium, The Economist devoted a special issue to Africa. And the main title of The Economist (2000) is "The Hopeless continent". And the articles that followed are the height of what can only be called "Afro-pessimism".

This reading grid is based on the idea that Black Africa is off to a bad start (Dumont, 1962). This title by René Dumont, dating from 1962, is repeated over and over again in many books, articles and various comments concerning the continent. The radical Afro-pessimism of some is fed by the idea that there are blockages maintained by the Africans themselves, which no development aid will be enough to overcome. In this context, The Economist had developed reflections that tended to indicate that economists have tried all the formulas and that, in the end, if rational economic formulas do not work, it is because the problem of Africa is Africa itself, it is the African youth itself, it is the Africans themselves.

\section{B - The hopeful continent: Africa rising}

In 2011, the same newspaper, The Economist, looking at what it had published in 2000, wrote this time "The hopeful continent: Africa rising" (The Economist, 2011)». What happened between the two limits? Ten years, of course. But in those ten years, what has actually happened to bring us out of the depths of Afro-pessimism for a title like this, which seems to be the very hallmark of Afro-optimism? The answer is that there has been a profound transformation of the African continent during this period. Transformations in terms of political governance initiatives but especially in terms of demographic trends.

\section{Demographic dynamics in Africa}

In less than half a century (2000-2050), the world population will experience two major trends:

- More young people in the developing world, more old people in the "rich" countries (Rabier and Djoufelkit, 2021). With $75 \%$ of the population under 35 years of age and only $3 \%$ over 65 years of age (2019) in Africa, the inclusion of young people in economic and social life remains and will remain the major challenge for public policies. The categorization "developed countries versus poor countries" will be increasingly coupled with an equally structuring categorization "old countries versus young countries".

- The unparalleled increase in the African population and a considerable decrease in the population of the rest of the world. The world's population is expected to increase by 2 billion people by the middle of the 21 st century, but then it will decrease (Vollset et al., 2020).

Academia Letters, October 2021

(C)2021 by the authors - Open Access — Distributed under CC BY 4.0

Corresponding Author: Joseph Mimbale, joseph_mimbale@yahoo.com

Citation: Mimbale, J., Mbutamuntu, J. (2021). AFRICAN YOUTH: Stimulus and brake to the effective implementation of the African Continental Free Trade Area. Academia Letters, Article 3802.

https://doi.org/10.20935/AL3802. 
Africa's population will continue to grow throughout the century and one in four people will be African.

\section{Dichotomous importance of African youth}

There are two fundamentally dichotomous arguments for why youth are important to the effective implementation of the AfCFTA.

\section{A - African youth as a catalyst for progress}

Demographic projections in Africa indicate the emergence of a continent composed mainly of young people (MO IBRAHIM FOUNDATION, 2019) - a youth capable of contributing to sustainable growth and development. Indeed, by 2050, one third of the world's young population is expected to live on the continent (Mariama, 2018). This involves Africa's large and rapidly growing youth workforce, which is a valuable asset with the potential to generate a demographic dividend, produce socio-economic gains - and stand out as a transformational change driver par excellence [7]. These young people can be a source of innovation, creativity, talent and energy on which the future prosperity of the continent will depend. Hence the importance of mobilizing them, raising their awareness and making them responsible for the implementation of the AfCFTA.

\section{B - African youth as an obstacle to progress}

Africa's youth also constitute a potential liability to regional initiatives such as the AfCFTA if nothing is done to: (1) find solutions to the unemployment problem; (2) boost quality job creation, (3) change the youth training paradigm and promote STEM.

It should be noted, first of all, that today, the AfCFTA is certainly intended to transform the 55 African countries, but there are prerequisites. Because Africa is called to reconcile with its youth and especially when we know that it has an extremely important youth representing $60 \%$ of the unemployed of the continent (World Bank, 2020) and that it is necessary to find work for him...In addition to high unemployment, African youth have few opportunities to find decent work. This is because young people often work in the informal economy-which is characterized by low wages, unsafe or exploitative working conditions, low productivity, and less stable employment. The latest report of the International Labor Organization (2018) on this subject, dating from 2018, reports that $94.9 \%$ of people aged 15 to 24 in Africa work in the informal economy. 
Also, access to quality education remains a challenge in Africa and is one of the many barriers limiting access to decent jobs. Yet African youth today need skills such as entrepreneurship, e-commerce, creativity, and technical innovation to make progress toward the Sustainable Development Goals. Therefore, STEM education will educate young people in the four specific subjects (Science, Technology, Engineering and Math) by adopting an interdisciplinary and applied approach - a foundation for innovation and a stimulus for initiative.

\section{Conclusion}

Mobilizing and relying on youth for effective implementation of the AfCFTA is of undeniable importance for two reasons. First, because youth are a catalyst for the continent's future progress. Second, because youth can be a liability if nothing is done to: (1) find solutions to the unemployment problem; (2) boost the creation of quality jobs, (3) change the youth training paradigm and promote STEM. 


\section{References}

Bitsch M-T (2008) Histoire de La Construction Européenne de 1945 à Nos Jours. Editions c. Paris.

CNUCED (2019) Le développement économique en Afrique. Génève. DOI: 10.18356/7485eaabfr.

Dumont R (1962) L'Afrique Noire Est Mal Partie. Seuil. Paris. Available at: https://www. seuil.com/ouvrage/l-afrique-noire-est-mal-partie-rene-dumont/9782021086447.

ILO (2018) Women and Men in the Informal Economy: A Statistical Picture. OIT. Third Edit. Genève. DOI: 10.1179/bac.2003.28.1.018.

Luke D, Ameso J and Bekele MG (2021) Entrée en vigueur de la ZLECAf en 2021. Available at: https://trade4devnews.enhancedif.org/fr/op-ed/entree-en-vigueur-de-la-zlecaf-en-2021 (accessed 17 April 2021).

Mariama S (2018) Figures of the week: Africa's growing youth population and human capital investments. Available at: https://www.brookings.edu/blog/africa-in-focus/2018/09/20/ figures-of-the-week-africas-growing-youth-population-and-human-capital-investments/ (accessed 18 April 2021).

MO IBRAHIM FOUNDATION (2019) Africa's Youth: Jobs or Migration? London.

Rabier S and Djoufelkit H (2021) Le basculement démographique du monde comme nouvel horizon du développement. Available at: https://ideas4development.org/basculementdemographique-horizon-developpement/ (accessed 17 October 2021).

The Economist (2000) The Hopeless continent. Available at: https://www.economist.com/ weeklyedition/2000-05-13 (accessed 16 March 2017).

The Economist (2011) The hopeful continent: Africa rising. Available at: https://www. economist.com/leaders/2011/12/03/africa-rising (accessed 15 March 2017).

Tomiwa O (2020) Kenya Leads Africa's Mobile Money Revolution with M-PESA Dominating over $98 \%$ of its Market. Available at: https://technext.ng/2020/07/06/kenya-leadsafricas-mobile-money-revolution-with-m-pesa-dominating-over-98-of-its-market/ (accessed 18 April 2021).

Vollset SE, Goren E, Yuan CW, et al. (2020) Fertility, mortality, migration, and population 
scenarios for 195 countries and territories from 2017 to 2100: a forecasting analysis for the Global Burden of Disease Study. The Lancet 396(10258). The Author(s). Published by Elsevier Ltd. This is an Open Access article under the CC BY 4.0 license: 1285-1306. DOI: 10.1016/S0140-6736(20)30677-2.

World Bank (2020) Chômage, total (\% de la population) (estimation modélisée OIT). Available at: https://donnees.banquemondiale.org/indicateur/SL.UEM.TOTL.ZS (accessed 19 March 2021). 